Tersedia online di: http://ejournal-balitbang.kkp.go.id/index.php/bawal
e-mail:bawal.puslitbangkan@ @mail.com
BAWAL wIDYA RISET PERIKANAN TANGKAP
Volume 9 Nomor 3 Desember 2017
e-ISSN: 2502-6410
BAWALr Akreditasi: 620/AU2/P2MI-LIPI/03/2015

\title{
SEBARAN FREKUENSI PANJANG, HUBUNGAN PANJANG-BERAT, TINGKAT KEMATANGAN GONAD DAN RATA-RATA UKURAN PERTAMA KALI MATANG \\ GONAD UDANG PUTIH (Penaeus merguiensis De Man, 1888) DI PERAIRAN KOTABARU, KALIMANTAN SELATAN
}

\section{LENGTH FREQUENCY, LENGTH-WEIGHT RELATIONSHIP, MATURITY STAGES AND LENGTH OF FIRST MATURE OF BANANA PRAWN (Penaeus merguiensis De Man, 1888) IN KOTABARU WATERS, SOUTH OF KALIMANTAN}

\author{
Tirtadanu*1, Suprapto $^{1}$ dan Ali Suman ${ }^{1}$ \\ ${ }^{1}$ Balai Penelitian Perikanan Laut, Jl. Raya Bogor KM. 47 Nanggewer Mekar, Cibinong, Bogor \\ Teregistrasi I tanggal: 11 Juli 2016; Diterima setelah perbaikan tanggal: 25 September 2017; \\ Disetujui terbit tanggal: 06 Oktober 2017
}

\begin{abstract}
ABSTRAK
Pengusahaan udang putih (Penaeus merguiensis De Man, 1888) di perairan sekitar Kotabaru memerlukan upaya pengelolaan agar perikanan udang dapat berkelanjutan.Salah satu informasi penting yang diperlukan sebagai dasar dalam pengelolaannya yaitu aspek biologi.Tujuan penelitian adalah mengkaji sebaran frekuensi panjang, hubungan panjang-berat, tingkat kematangan gonad dan rata-rata ukuran pertama kali matang gonad udang putih di perairan sekitar Kotabaru. Pengumpulan data diperoleh dari tempat pendaratan udang di Kotabaru pada bulan Januari - November 2016. Metode pengambilan sampel yang digunakan adalah random sampling. Hasil penelitian menunjukkan ukuran udang putih yang tertangkap cenderung kecil dengan ukuran berkisar antara 14 - $46 \mathrm{mmCL}$ dan rata-rata sebesar $26 \pm 3,7 \mathrm{mmCL}$ pada udang jantan dan 28,5 $\pm 5,3 \mathrm{mmCL}$ pada udang betina. Pola pertumbuhan bersifat allometrik negatif dan telah terjadi penurunan bobot dibandingkan beberapa tahun sebelumnya. Proporsi tertinggi udang matang gonad terjadi pada bulan Maret sehingga diduga merupakan puncak pemijahan udang putih.Ukuran pertama kali tertangkap udang $(\mathrm{Lc}=28,1 \mathrm{mmCL})$ lebih kecil dibandingkan ukuran pertama kali matang gonad ( $\mathrm{Lm}=35,3 \mathrm{mmCL}$ ) sehingga sebagian besar udang yang tertangkap belum melakukan pemijahan. Dalam rangka menjaga keberlanjutan sumberdaya udang putih di Kotabaru, disarankan melakukan penutupan penangkapan di bulan Maret dan penggunaan alat tangkap ramah lingkungan dengan ukuran minimum tertangkap lebih besar dari $35 \mathrm{mmCL}$ atau kurang dari 27 ekor dalam $1 \mathrm{~kg}$.
\end{abstract}

Kata Kunci: Sebaran ukuran; kematangan gonad; Penaeus merguiensis; Kotabaru

\section{ABSTRACT}

The exploitation of banana prawn (Penaeus merguiensis De Man, 1888) in Kotabaru Waters need management strategy, so the prawn fisheries in Kotabaru waters could be sustainably exploited. The important information needed for its basis management are was biological aspects of banana prawn. The aim of this research were to study about length frequency, length-weight relationship, maturity stages and length at first first mature of banana prawn in Kotabaru Waters. The research was conducted at landing site of prawn in Kotabaru and the samples were collected in January - November 2016. The method used for sampling was random sampling. The results showed that the size of banana prawn tend to become smaller with the size between 14-46 $\mathrm{mmCL}$ and the mean size were $26 \pm 3,7 \mathrm{mmCL}$ for male and 28,5 $\pm 5,3 \mathrm{mmCL}$ for female. The growth pattern of banana prawn was allometric negative and the weights decreased from the previous years. The highest proportion of mature prawns was in March, likely suggestes to be the spawning season of banana prawn. Length at first captured of banana prawns $(L c=28,1 \mathrm{mmCL})$ was lower than length at first matured $(\mathrm{Lm}=35,3$ mmCL) so most of prawns captured has not spawn yet. For sustainability of banana prawn resources in 
Kotabaru Waters, it is suggested to close fishing season in March and minimum legal size should be bigger than $35 \mathrm{mmCL}$ or less than 27 prawns in $1 \mathrm{~kg}$.

\section{Keywords: Length distribution; gonad maturity; Penaeus merguiensis; Kotabaru}

\section{PENDAHULUAN}

Perairan Kotabaru merupakan salah satu perairan pantai di Kalimantan Selatan yang termasuk dalam Wilayah Pengelolaan Perikanan (WPP) 713, Selat Makassar. Selat Makassar memiliki kedalaman mencapai lebih dari seribu meter sehingga perikanan udang hanya terdapat di sekitar perairan pantai yang relatif dangkal. Perairan pantai Kotabaru memiliki substrat dasar yang berlumpur dan relatif dangkal sehingga merupakan daerah yang potensial bagi perikanan udang.

Aktivitas penangkapan udang telah menjadi mata pencaharian utama bagi nelayan di Kotabaru dan penangkapannya telah dilakukan sejak tahun 1970-an dengan jenis udang yang paling dominan tertangkap adalah udang putih (Penaeus merguiensis de Man, 1888) (Naamin \& Uktoselya, 1976). Nelayan di Kotabaru umumnya menangkap udang dengan lampara dasar dan jaring berlapis (trammel net). Berdasarkan data statistik Direktorat Jenderal Perikanan Tangkap tahun 2015, jumlah lampara dasar yang dioperasikan di perairan pantai Timur Kalimantan, provinsi Kalimantan Selatan mencapai 9.440 unit dan jaring berlapis sebesar 2.705 unit serta produksi udang putih mencapai 5.141 ton.

Hasil penelitian Suman \& Umar (2010) menunjukkan laju pengusahaan udang putih di perairan Kotabaru berada dalam tahapan overfishing. Informasi terbaru tentang aspek biologi udang putih diperlukan sebagai dasar dalam pengelolaan perikanan udang yang berkelanjutan di Kotabaru. Penelitian ini bertujuan untuk mengkaji sebaran frekuensi panjang, hubungan panjang-berat, tingkat kematangan gonad dan rata-rata ukuran pertama kali matang gonad udang putih di perairan sekitar Kotabaru.

\section{BAHANDANMETODE}

Pengambilan contoh udang putih (Penaeus merguiensis) dilakukan pada bulan Januari - November 2016, diperoleh dari hasil tangkapan nelayan di sebelah utara Pulau Laut (Gambar 1).

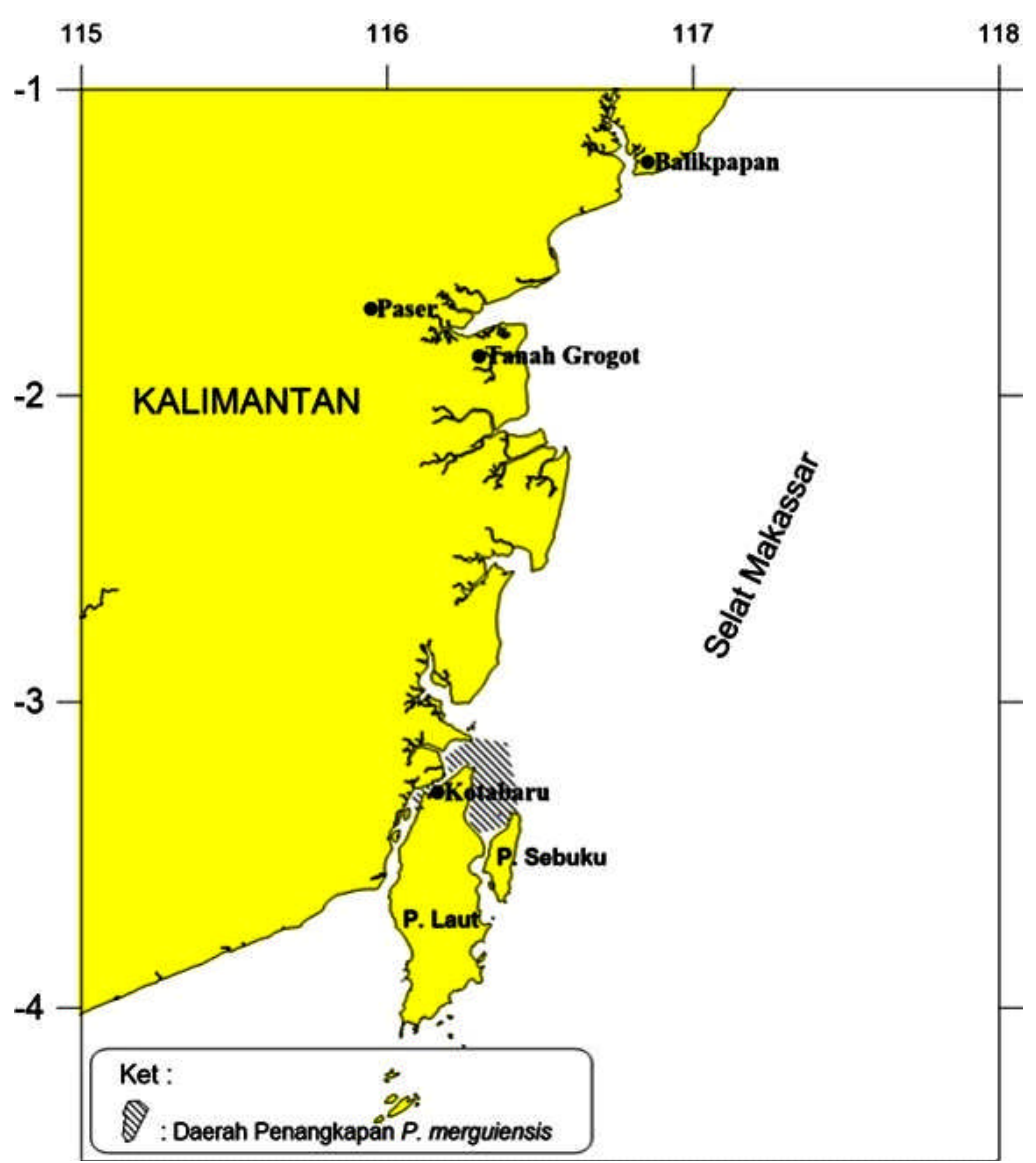

Gambar 1. Peta daerah penangkapan udang di perairan Kotabaru, Kalimantan Selatan.

Figure 1. Map showing fishing ground for shrimps in Kotabaru waters, South of Kalimantan. 
Sampel udang yang diperoleh merupakan hasil tangkapan nelayan dengan alat tangkap lampara dasar yang dioperasikan di sekitar perairan pantai Pulau Laut Utara Kotabaru dengan kedalaman maksimum 20 m dan substrat dasar yang berlumpur.Pengamatan sampel udang meliputi pengukuran panjang karapas, berat, jenis kelamin dan tingkat kematangan gonad tiap bulan. Analisis data yang dilakukan meliputi frekuensi panjang, hubungan panjang berat, nisbah kelamin, tingkat kematangan gonad, ukuran rata-rata pertama kali matang gonad (Lm) dan ukuran rata-rata pertama kali tertangkap (Lc).

Struktur ukuran panjang karapas dibagi dalam beberapa kelas panjang dan ditampilkan dalam grafik batang. Hubungan panjang berat udang mengikuti hukum kubik (Bal \& Rao,1984; King, 1995) yaitu:

$\mathrm{W}=\mathrm{aL}^{\mathrm{b}}$

Dimana;

$\mathrm{W}=\operatorname{berat}($ gram$)$

$\mathrm{L}=\operatorname{panjang}(\mathrm{mm})$

$\mathrm{a}, \mathrm{b}=$ adalah konstanta

Analisis faktor kondisi udang menggunakan persamaan (King, 1995):

$\mathrm{Kt}=10^{2} \mathrm{~W} / \mathrm{L}^{3}$

Dimana;

$\mathrm{Kt}=$ faktor kondisi

$\mathrm{W}=$ bobot rata-rata udang (gr)

$\mathrm{L}$ = panjang rata-rata karapas udang $(\mathrm{mm})$

Jumlah udang jantan dan betina dibandingkan dalam penentuan nisbah kelamin. Penentuan seimbang tidaknya nisbah kelamin jantan dan betina dilakukan uji Chi-square (Walpole, 1993).

Kematangan gonad udang betina diamati secara visual pada bagian punggungnya yang diklasifikasi berdasarkan Motoh (1981). Rata-rata matang gonad (CLm) diperoleh dengan memasukkan nilai panjang karapas dan $\mathrm{P}_{\mathrm{Lm}}$ ke dalam bentuk grafik fungsi logistik (King, 1995). Persamaan yang digunakan sebagai berikut:

$$
\mathrm{P}_{\mathrm{CLM}}=\frac{1}{1+\operatorname{EXP}(\mathrm{aCl}+\mathrm{b})}
$$

Nilai panjang karapas udang pertama kali tertangkap (CLc) diperoleh melalui pendekatan fungsi logistik dengan persamaan (Sparre \& Venema, 1992):

$$
\mathrm{S}_{\mathrm{CL}}=\frac{1}{1+\operatorname{EXP}(\mathrm{a}-\mathrm{b} * \mathrm{CL})}
$$

Di mana: $\mathrm{S}_{\mathrm{CL}}$ adalah selektivitas alat tangkap trawl, a dan b adalah konstanta, CL adalah panjang karapas udang dan nilai CLc diperoleh dari a/b.

\section{HASIL DAN BAHASAN Hasil}

\section{Frekuensi Panjang}

Sampel udang putih yang diperoleh selama penelitian sebanyak 940 ekor udang yang terdiri dari 392 ekor udang jantan dan 548 udang betina. Ukuran udang putih yang tertangkap di Kotabaru berkisar antara $14-46$ mmCL. Ukuran udang betina lebih besar dibandingkan jantan dengan rata-rata ukuran udang jantan $26 \pm 3,7 \mathrm{mmCL}$ dan udang betina 28,5 $\pm 5,3 \mathrm{mmCL}$. Modus ukuran udang betina adalah $30 \mathrm{~mm}$ dan udang jantan $28 \mathrm{~mm}$ (Gambar 2).

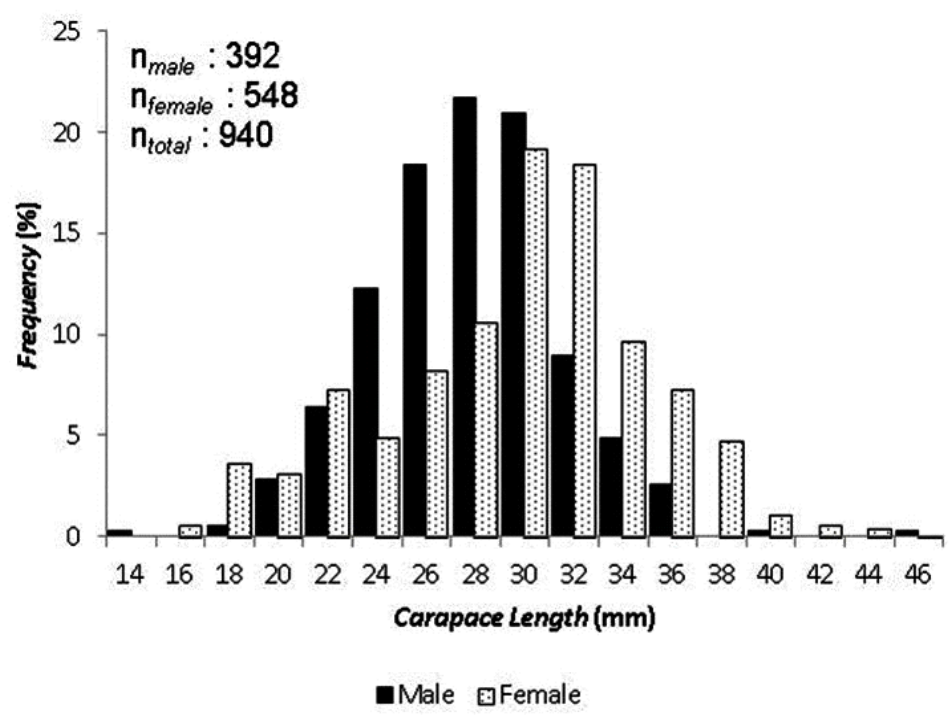

Gambar 2. Frekuensi panjang udang putih di perairan Kotabaru, Kalimantan Selatan.

Figure 2. Length frequency of banana prawn in Kotabaru waters, South of Kalimantan. 


\section{Hubungan Panjang-Berat}

Pertumbuhan udang putih jantan dan betina menunjukkan sifat pertumbuhan allometrik negatif $(b<3)$. Berat rata-rata udang putih betina adalah 26,3 $\pm 9,4$
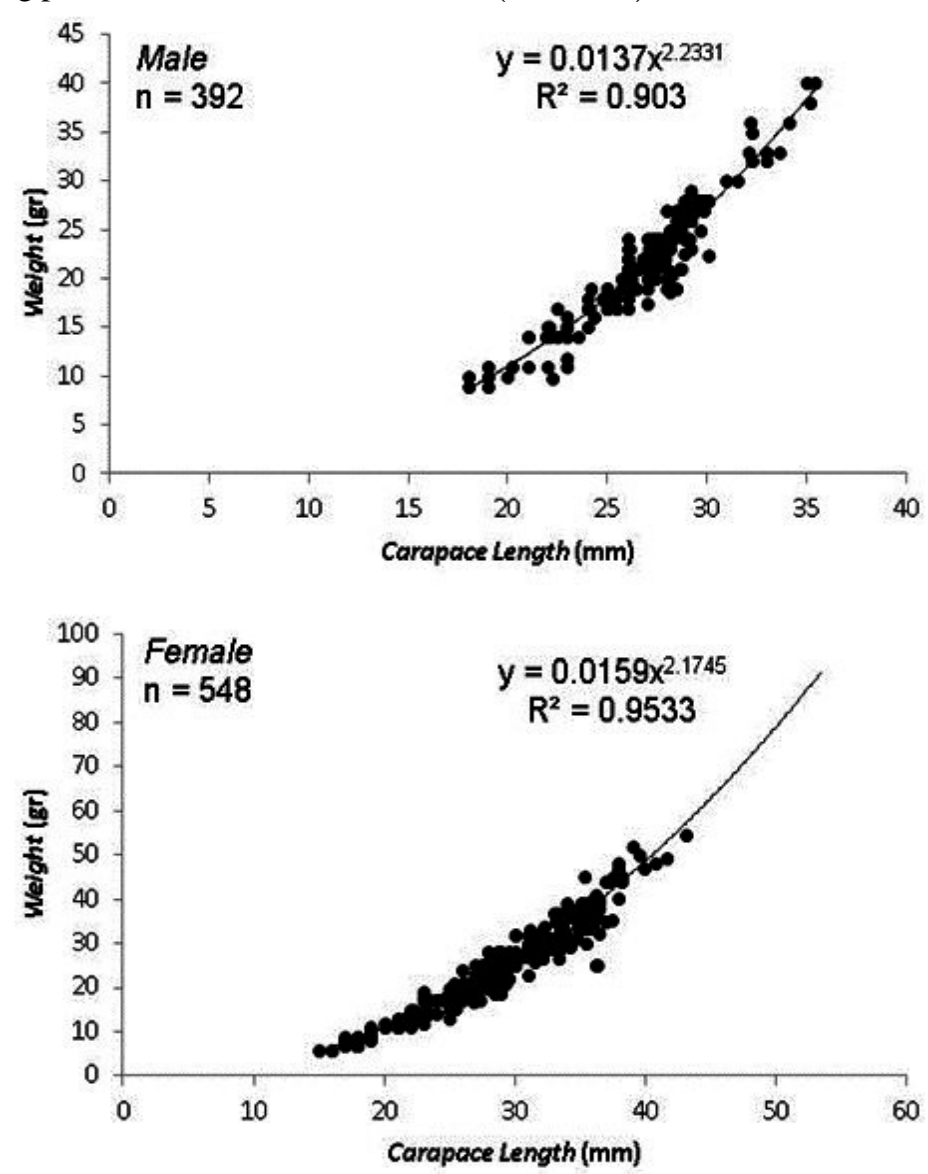

Gambar 3. Hubungan panjang-berat udang putih jantan dan betina di perairan Kotabaru, Kalimantan Selatan.

Figure 3. Length-weight relationship of male and female banana prawn in Kotabaru waters, South of Kalimantan.

\section{Faktor Kondisi (Kt)}

Rentang faktor kondisi (Kt) udang putih di perairan Kotabaru berkisar antara 0,079 - 0,184 dan rata-rata sebesar 0,11 . Faktor kondisi tertinggi berada pada bulan Agustus dan terendah pada bulan Maret (Tabel 1).

\section{Nisbah Kelamin dan Tingkat Kematangan Gonad}

Nisbah kelamin udang putih yang tertangkap di Kotabaru menunjukkan kondisi tidak seimbang atau berbeda dari perbandingan $1: 1$. Udang putih betina lebih dominan dibandingkan jantan dengan perbandingan jantan dan betina adalah $1: 1,4$.

Sebagian besar proporsi tingkat kematangan gonad udang betina pada bulan Januari-November didominasi gr dan jantan adalah $22,9 \pm 6,5$ gr. Nilai koefisien b pada udang putih jantan adalah 2,23 dan betina adalah 2,17. Persamaan hubungan panjang-berat udang putih jantan yaitu $W=0,0137 \mathrm{~L}^{2,23}$ dan udang putih betina $W=0,0159 \mathrm{~L}^{2,17}$ (Gambar 3).

oleh udang betina yang belum matang gonad.Puncak proporsi udang betina matang gonad yaitu pada bulan Maret dengan proporsi udang betina matang sebesar $50 \%$ (Gambar 4).

\section{Rata-Rata Ukuran Pertama Kali Matang Gonad (Lm) Dan Rata-Rata Ukuran Pertama Kali Tertangkap (Lc)}

Panjang pertama kali matang gonad udang putih betina (Lm) diperoleh dengan persamaan fungsi logistik dengan jarak ukuran yang digunakan adalah $2 \mathrm{~mm}$. Ukuran pertama kali matang gonad (Lm) udang putih di perairan Kotabaru sebesar 35,3 mmCL (Gambar 5). Ukuran pertama kali matang gonad udang putih sebesar 35,3 mmCL memiliki berat sebesar 37 gram atau dalam $1 \mathrm{~kg}$ terdapat sekitar 27 ekor udang. 
Tabel 1. Faktor kondisi udang putih (P. merguiensis) di perairan Kotabaru, Kalimantan Selatan.

Table 1. Condition factor of banana prawn (P. merguiensis) in Kotabaru waters, South of Kalimantan.

\begin{tabular}{cccc}
$\begin{array}{c}\text { Bulan/ } \\
\text { Months }\end{array}$ & $\begin{array}{c}\text { Rata-Rata Panjang }(\mathbf{m m C L}) / \\
\text { Mean of } \boldsymbol{C L}(\mathbf{m m} \boldsymbol{C L})\end{array}$ & $\begin{array}{c}\text { Rata-Rata W }(\mathbf{g r}) / \\
\text { Mean of } \boldsymbol{W}(\mathbf{g r})\end{array}$ & $\begin{array}{c}\text { Faktor Kondisi }(\mathbf{K t}) / \\
\text { Condition Factor }(\boldsymbol{K} \boldsymbol{t})\end{array}$ \\
\hline Januari & 21.60 & 13.36 & 0.133 \\
Maret & 34.37 & 31.98 & 0.079 \\
April & 30.48 & 27.84 & 0.098 \\
Mei & 30.88 & 28.50 & 0.097 \\
Juli & 29.27 & 27.59 & 0.110 \\
Agustus & 24.71 & 27.83 & 0.184 \\
September & 31.82 & 30.43 & 0.094 \\
November & 31.86 & 27.08 & 0.084 \\
\hline
\end{tabular}

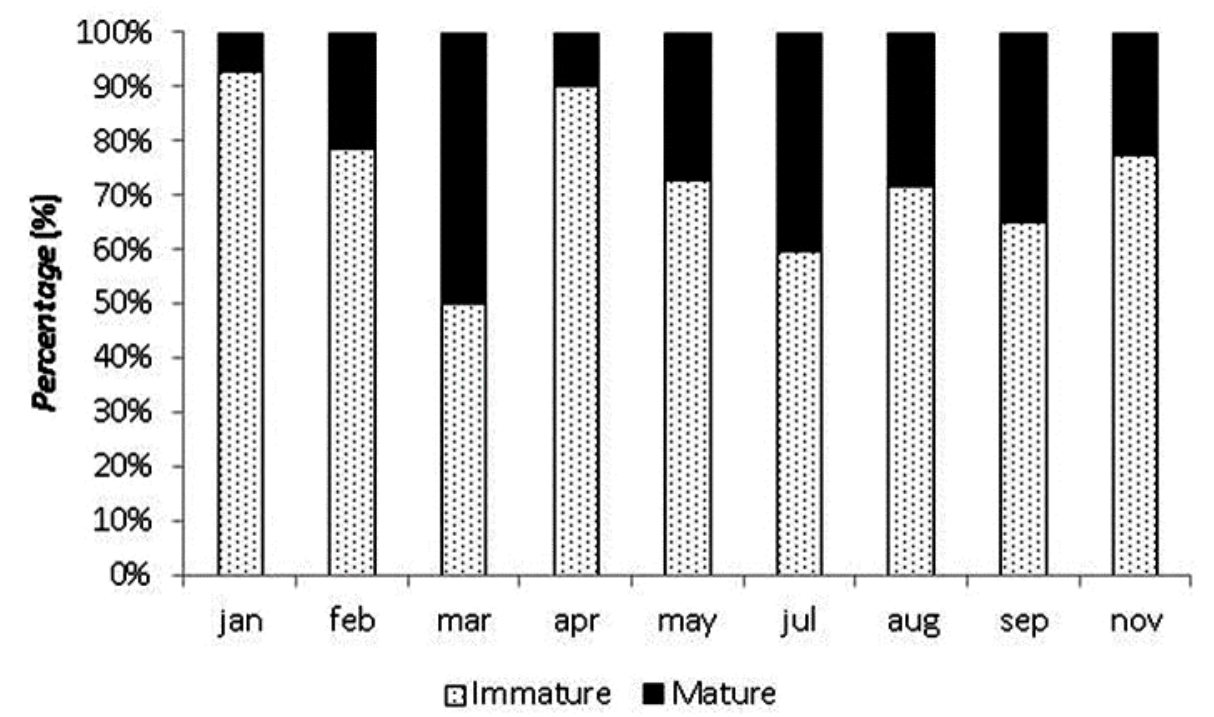

Gambar 4. Proporsi udang putih betina matang di perairan Kotabaru, Kalimantan Selatan, Immature: Stadia I dan II; Mature: stadia III dan IV.

Figure 4. Proportion of mature female for banana prawn in Kotabaru waters, South of Kalimantan. Immature: Stadia I and II; Mature: Stadia III and IV.

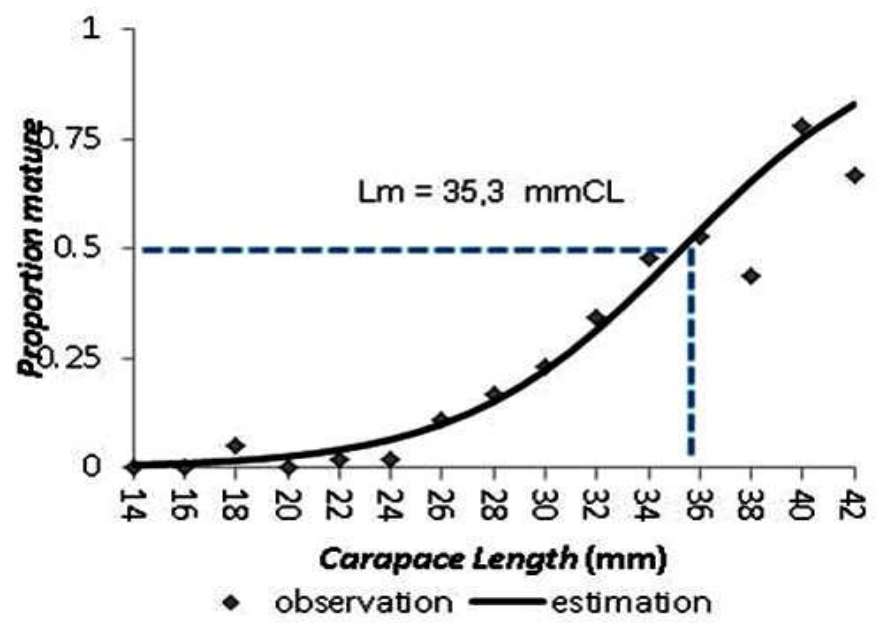

Gambar 5. Panjang pertama kali matang gonad (Lm) udang putih di Perairan Kotabaru, Kalimantan Selatan.

Figure 5. Length at first matured $(\mathrm{Lm})$ of banana prawn in Kotabaru waters, South of Kalimantan. 
Panjang pertama kali tertangkap (Lc) udang putih dengan alat tangkap lampara dasar diperoleh dengan memasukkan proporsi panjang karapas udang dalam persamaan fungsi logistik.Interval panjang yang digunakan bagi masing-masing kelompok ukuran adalah
$2 \mathrm{~mm}$ dan diperoleh ukuran rata-rata pertama kali tertangkap adalah 28,1 mmCL (Gambar 6). Ukuran ratarata pertama kali tertangkap sebesar 28,1 mmCL memiliki berat sebesar 22,4 gram atau dalam $1 \mathrm{~kg}$ terdapat sekitar 44-45 ekor udang.

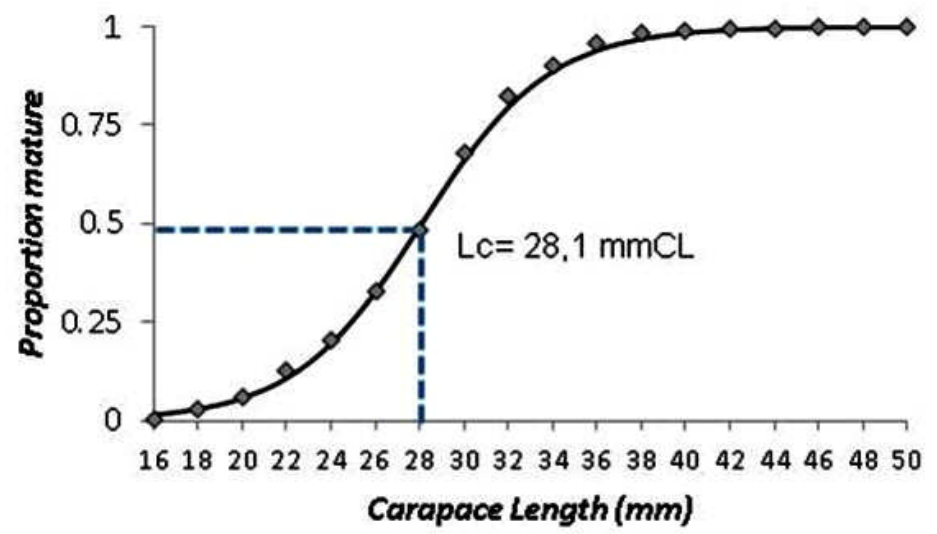

-estimation

Gambar 6. Panjang pertama kali tertangkap (Lc) udang putih di Perairan Kotabaru, Kalimantan Selatan.

Figure 6. Length at first captured (Lc) of banana prawn in Kotabaru waters, South of Kalimantan.

\section{Bahasan}

Ukuran udang putih (Penaeus merguiensis De Man, 1888)yang tertangkap di perairan Kotabaru saat ini pada tahun 2016 sebesar 14-46 mmCL, lebih besar dibandingkan ukuran yang tertangkap di perairan Kotabaru pada 4 tahun sebelumnya yaitu di tahun 2011 sebesar 22-40 mmCL, namun lebih kecil dibandingkan udang putih yang tertangkap di perairan Kotabaru pada 40 tahun sebelumnya yaitu di tahun 1976 sebesar 20-47 mmCL (Damora \& Wedjatmiko, 2012; Naamin \& Uktolseya, 1976).Ukuran rata-rata udang yang tertangkap di perairan Kotabaru saat ini sebesar $26 \mathrm{~mm}$ pada jantan dan $28,5 \mathrm{~mm}$ pada betina juga lebih kecil dibandingkan ukuran ratarata udang putih yang tertangkap di perairan Kotabaru pada tahun 1976 sebesar $31 \mathrm{~mm}$ pada jantan dan $36,6 \mathrm{~mm}$ pada betina (Naamin \& Uktolseya, 1976). Kondisi tersebut menunjukkan terjadinya perubahan ukuran udang yang tertangkap di perairan Kotabaru di mana ukurannya tergolong mengecil jika dibandingkan pada tahun 1970an. Ukuran udang yang mengecil diduga disebabkan oleh tekanan penangkapan yang tinggi dimana pemanfaatannya telah dilaporkan mengarah pada tekanan penangkapan berlebih (overfishing) di tahun 2006 (Suman \& Umar, 2010). Pengelolaan yang disarankan sebagai upaya pemulihan ukuran udang yang tertangkap adalah menetapkan ukuran minimum tertangkap lebih besar dari ukuran rata-rata pertama kali matang gonad dengan ukuran 35,3 mmCL atau dengan berat lebih besar dari 37 gram yang berarti dalam $1 \mathrm{~kg}$ terdapat kurang dari 27 ekor udang.

Pola pertumbuhan udang putih di daerah penelitian bersifat allometrik negatif dengan nilai koefisien b sebesar
2,23 pada jantan dan 2,17 pada betina. Kondisi tersebut menunjukkan pertambahan panjang udang lebih cepat dibandingkan dengan beratnya. Koefisien udang putih di perairan Kotabaru pada tahun 2011 sebesar 2,45 pada jantan dan 2,52 pada betina (Damora \& Wedjatmiko, 2012). Koefisien b udang putih di perairan Kotabaru saat ini di tahun 2016 lebih kecil dibandingkan 4 tahun sebelumnya di tahun 2011 menunjukkan adanya penurunan bobot udang saat ini dibandingkan beberapa tahun sebelumnya. Penurunan bobot udang putih di perairan Kotabaru diduga disebabkan oleh perubahan ketersediaan makanan di alam dan perubahan faktor lingkungan.Pengelolaan yang disarankan adalah penggunaan alat tangkap yang ramah lingkungan tanpa merusak kondisi substrat dasar perairan yang berlumpur di mana merupakan habitat penting bagi udang putih.

Faktor kondisi udang putih di daerah penelitian berkisar antara 0,079-0,184 dengan faktor kondisi terendah adalah pada bulan Maret dan tertinggi pada bulan Agustus. Faktor kondisi udang dapat menggambarkan kondisi kesehatan umum udang, tingkat kegemukan dan periode kematangan gonad (Pauly, 1983). Faktor kondisi (K) udang putih di daerah penelitian tergolong rendah menunjukkan bahwa tingkat kegemukan udang yang rendah dipengaruhi oleh ketersediaan makanan bagi udang putih di perairan Kotabaru.Faktor kondisi (K) udang putih terendah di bulan Maret disebabkan oleh puncak periode reproduksi udang putih terjadi pada bulan Maret sehingga konversi makanan digunakan untuk kematangan gonad (Olamide et al., 2014).Hal tersebut diperkuat dengan proporsi tingkat kematangan gonad tertinggi udang yang ditemukan yaitu 
pada bulan Maret dengan proporsi udang betina matang gonad sebesar $50 \%$.

Pada penelitian sebelumnya di tahun 2010 menunjukkan puncak pemijahan udang putih terjadi pada bulan September (Suman \& Umar, 2010).Pada periode ini, pemijahan udang putih terlihat berlangsung pada beberapa puncak yaitu bulan Maret, Juli dan September dengan puncak tertinggi yaitu pada bulan Maret.Informasi terkait proporsi tingkat kematangan gonad pada bulan Maret belum tersedia pada penelitian sebelumnya sehingga informasi tersebut dapat menjadi evaluasi dalam penentuan musim penangkapan udang putih di perairan Kotabaru. Udang putih yang dominan di perairan Kotabaru adalah udang betina dengan perbandingan jantan dan betina $1: 1,4$. Kondisi tersebut tergolong cukup baik bagi pembaruan populasi udang putih di perairan Kotabaru.

Panjang rata-rata pertama kali tertangkap udang putih (Lc) dengan alat tangkap lampara dasar di perairan Kotabaru, Kalimantan Selatan sebesar 28,1 mmCL lebih kecil dibandingkan di perairan Sampit, Kalimantan Tengah sebesar 30,05 mmCL (Nurdin \& Kembaren, 2015). Hal tersebut menunjukkan bahwa sebagian besar udang yang tertangkap di Kotabaru berukuran lebih kecil yang dapat disebabkan oleh perbedaan alat tangkap dan perbedaan karakteristik biologi udang.Ukuran rata-rata pertama kali matang gonad (Lm) udang putih di daerah penelitian sebesar 35,3 mmCL atau memiliki berat sebesar 37 gram yang berarti terdapat 27 ekor udang dalam $1 \mathrm{~kg}$.Ukuran rata-rata pertama kali matang gonad tersebut dapat digunakan sebagai salah satu indikator tekanan penangkapan (Lappalainen et al., 2016).

Rata-rata ukuran pertama kali tertangkap (Lc) udang putih di perairan Kotabaru sebesar 28,1 mmCL lebih kecil dibandingkan rata-rata ukuran pertama kali matang gonad (Lm) sebesar 35,3 mmCL. Kondisi tersebut dapat mengganggu penambahan baru populasi udang putih disebabkan sebagian besar udang yang tertangkap belum melakukan pemijahan. Sebagai upaya menjaga kelestarian dan keberlanjutan sumberdaya udang putih di Kotabaru, pengelolaan yang disarankan sebagai opsi kebijakan yaitu penggunaan alat tangkap ramah lingkungan dengan ukuran udang putih tertangkap lebih besar dari $35 \mathrm{mmCL}$ atau kurang dari 27 ekor dalam $1 \mathrm{~kg}$ dan penutupan musim penangkapan di bulan Maret.

\section{KESIMPULAN}

Ukuran udang putih yang tertangkap di perairan Kotabaru saat ini cenderung mengecil dengan ukuran tertangkap berkisar antara 14 - 46 mmCL.Pola pertumbuhan udang putih (P. merguiensis) di perairan Kotabaru bersifat allometrik negatif dan cenderung mengalami penurunan bobot dibandingkan beberapa tahun sebelumnya.Proporsi udang putih matang gonad tertinggi ditemukan pada bulan Maret yang merupakan puncak musim pemijahan udang putih. Rata-rata ukuran pertama kali tertangkap udang ( $\mathrm{Lc}=28,1 \mathrm{mmCL}$ ) lebih kecil dibandingkan rata-rata ukuran pertama kali matang gonad $(\mathrm{Lm}=35,3 \mathrm{mmCL})$ sehingga sebagian besar udang yang tertangkap belum melakukan pemijahan. Pengelolaan yang disarankan untuk menjaga keberlanjutan sumberdaya udang putih di perairan Kotabaru yaitu melakukan penutupan penangkapan di bulan Maret dan penggunaan alat tangkap ramah lingkungan dengan ukuran minimum tertangkap lebih besar dari $35 \mathrm{mmCL}$ atau kurang dari 27 ekor dalam $1 \mathrm{~kg}$.

\section{PERSANTUNAN}

Tulisan ini merupakan bagian dari kegiatan penelitian "Karakteristik Biologi Perikanan, Potensi, Produksi dan Habitat Sumber Daya Ikan di perairan WPP 713" yang diselenggarakan oleh Balai Penelitian Perikanan Laut, Muara Baru, Jakarta.

\section{DAFTAR PUSTAKA}

Bal, D.V. \& Rao, K. V. (1984). Marine fisheries (p. 5 - 24). Tata Mc. Graw-Hill Publishing Company Limited, New Delhi.

Damora, A. \& Wedjatmiko. (2012). Dinamika populasi udang jerbung (Penaeus merguiensis) di perairan Kota Baru, Kalimantan Selatan (p. 15-27). Dalam Status Pemanfaatan Sumberdaya Ikan di Perairan Selat Makassar Teluk Bone, Laut Flores dan Laut Banda Indonesia: Balai Riset Perikanan Laut. IPB Press.

Direktorat Jenderal Perikanan Tangkap. (2015). Statistik perikanan tangkap Indonesia menurut Provinsi (p. 325). Direktorat Jenderal Perikanan Tangkap.

King M. (1995). Fishery Biology, Assessment and Management (p. 341). United Kingdom: Fishing New Books.

Lappalainen, A., Saks, L., Sustar, M., Heikinheimo, O., Jurgens, K., Kokkonen, E., Kurkilahti, M., Verliin, A. \& Vetemaa, M. (2016). Length at maturity as a potential indicator of fishing pressure effects on coastal pikeperch (Sander lucioperca) stocks in the northern Baltic Sea. Fisheries Research. 174, 47-57.

Motoh, H. (1981). Studies on the fisheries biology of the giant tiger prawn, Penaeus monodon, in the Philippines ( $\mathrm{p} 128)$. SEAFDEC Tech.

Naamin, N. \& Uktoselya, J. C. B. (1976). Status perikanan udang di perairan Kalimantan Selatan dan 
Timur.Marine Fisheries Research Report, Marine Fisheries Research Institute. 2, 1-82.

Nurdin, E. \& Kembaren, D.D. (2015). Parameter populasi udang putih (Penaeus merguiensis) di Perairan Sampit dan Sekitarnya, Kalimantan Tengah. BAWAL. 7(2), 103109.

Olamide, O., Adefemi, A., \& Oluayo, B. (2014). Lengthweight relationship and condition factor of prawns in coastal waters of Ondo state, South West, Nigeria. International Journal of Fisheries and Aquatic Studies. 1(3), 137-142.

Pauly, D. (1983). Some simple methods for the assessment of tropical fish stocks. Rome. FAO Fisheries Tech. p 234.
Sparre, P. \& Venema, S.C. (1992). Introduction to tropical fish stock asseessment part 1.Manual. Fao Fish.Tech. Pap. (306/1). Rev.1:376 p.

Suman. A. \& Umar. (2010). Dinamika populasi udang putih (Penaeus merguiensis De Man) di Perairan Kotabaru, Kalimantan Selatan. J. Lit. Perikan. Ind. 16(1), 29-33.

Walpole, R.V. E. (1993). Pengantar statistik (p. 321). Terjemahan B. Sumantri (Edisi Tiga). PT. Gramedia. Jakarta. 